で与えられます。ここで， $v_{\theta}$ は円筒容器入口における円

周方向の速度, $v_{r}$ は半径方向の速度分布, $R$ は穴の半 径， $H$ はネットの高さを表します．S が大きいほど乱流 になります。な抢，この実験は，文献 7)を参考にして行 いました。

1)～5）仙前号参照

6) Y. Miura, Journal of Atmospheric Sciences, 43 (1986) 26-39.

7) C. R. Church, J. T. Snow and E. W. Agee, Bulletin American Meteorological Society, 58 (1977) 900-908.

手作り実験あれこれ——私のアイディア $(2) *$

大島 裕子**

\title{
Hand-made Experiments; My Ideas (2)
}

\author{
Yuko Oshima
}

\section{ベンチュリー管（ベルヌーイの定理）}

圧力差から速度を知る，また流れの速さによって圧 力が違うことを示す装置としてのベンチュリー管は, 教 科書では断面図で管径の異なる管 $S_{0}, S_{1}$ にその異なる径 の部分 $\mathrm{A} ， \mathrm{~B}$ で各々に垂直な管を立てたものが示されて います（図 1)。そして $\mathrm{A}$ 点の速度 $U_{0}$ が $\mathrm{B}$ 点で $U_{1} に な$ ると $h$ が圧力差として示され, これより速度を求めるこ とが出来ます。このようなものが売られているかは知り ませんが，手作り実験で示す道具を探してみました。

理科の実験道具として売っている径の異なる 2 本のプ ラスチック製 $\mathrm{T}$ 字管 (内径 $5 \mathrm{~mm}, 9 \mathrm{~mm}$ を使用)をつな ぎ，垂直方向に外径 $6 \mathrm{~mm}$ 程度のガラス管を立てます (図 2).これの一方を水道の蛇口にホーースでつなき，水 を流せば水頭に差が示されます。他方の口につないだ ホースの出口の高さを調節して流量を調節すれば，2本 のガラス管に水頭差が示されます，流量を増加させれば 差も大きくなることを見ることが出来ます。

さて，水を流す方向を逆にしたらどうでしょうか．流 量を同じにしても，水頭差は先ほどとは同じになりませ ん. 太い方から細い方へとつないだ場合より，細い方か ら太い方への場合の方が差は小さくなります。これはい わゆる圧力損失が細い場合の方が大きいためです， 2 本 の T字管の径の違いが大きと差も大きく出るのです が, 圧力損失も大きく, 差がガラス管の長さでは収まら なくなってしまいます。

ベルヌーイの定理だけでなく，実際の流れには粘性が あること，圧力損失があることなどを実感として示すこ とが出来ます。

* 原稿受付 1997 年 6 月 20 日

** 正会員 (秼りコー

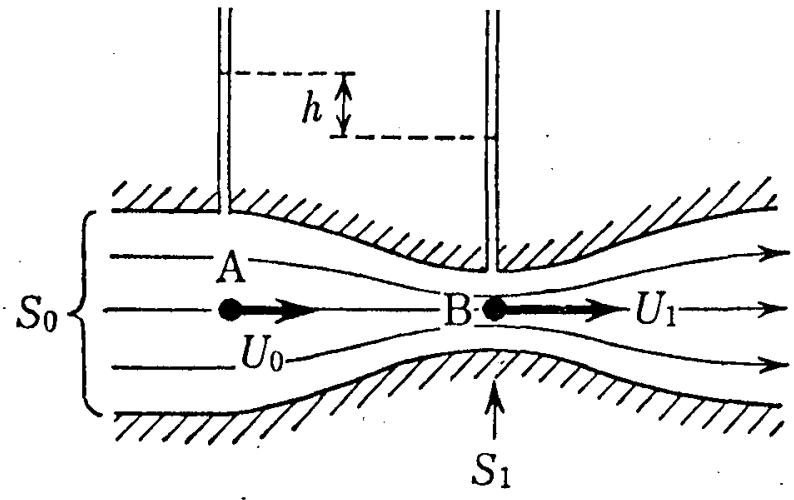

図 1 ベンチュリー管

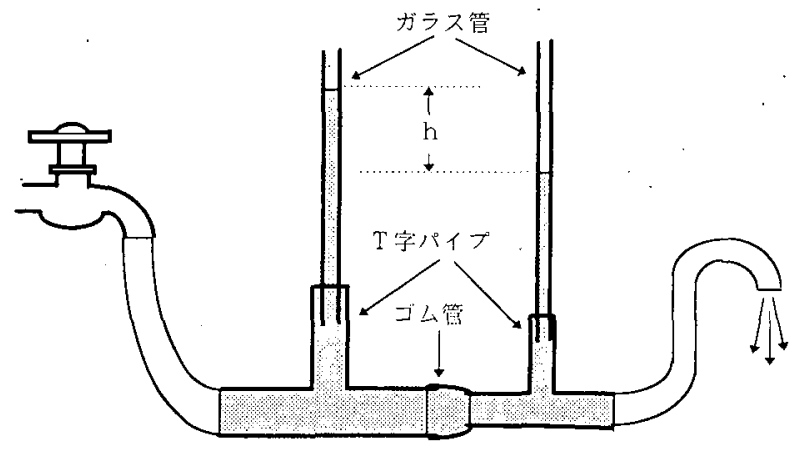

图 2 流す方向を変えると水頭差 $h$ が変ります 